\title{
1 The rise of ethical value in global trade networks
}

\author{
Warwick E. Murray, Kelle Howson and John \\ Overton
}

\section{INTRODUCTION}

Consumers in supermarkets, local stores and produce markets, and on a plethora of online virtual stores, are faced with a bewildering array of foods and beverages on offer from producers across the globe. Significant globalisation and liberalisation of trade over the past three decades has greatly increased the range of fresh and processed foodstuffs available just as it has often lowered the price of such goods. Consumers have been linked to places and systems of production through complex chains and networks that span the globe. Some are small and local linkages, as in local produce markets where growers sell direct to consumers; others are very large and complex, combining agro-commodities from different places, in sometimes large-scale industrial manufacturing processes where the origin and nature of raw materials becomes anonymised. In many cases, it is these latter Fordist systems of food and beverage production that have come to dominate, providing cheap, uniform products with brand names and characteristics recognisable and available worldwide.

Yet many consumers have eschewed these global products and brands, having become aware of their often-deleterious effects on human and environmental well-being, and been motivated to seek healthy, safe and clean alternatives. They seek virtuous products - ethical products - those that don't harm the environment, don't exploit workers and come from particular identifiable places and communities. However, this is no simple task. How can a potential buyer of a bottle of wine, or a bunch of asparagus, or a bag of apples, be assured of where they come from, how and by whom they have been produced and what remains in the product in the form of chemical residues or additives? As a result, many products come with claims and certification of their authenticity of origin, method of production and integrity of contents - their ethicality. These claims - often but not always supported by robust regulatory and auditing systems - serve to link consumer decisions to imaginaries 
of production, involving combinations of people, cultures, communities, environments, places, traditions and techniques. Ethicality is proclaimed, valued and incorporated in practice and often reflected in (higher) price. What is thus linked in the minds of consumers is mirrored by real - and often highly complex - networks of production, processing, transport, wholesaling and retailing. Throughout these networks, value is created, traded, augmented and appropriated by a wide variety of institutions and individuals.

This book is concerned with these networks, the way they are constructed, regulated and operated. We are also focused on the idea of value, particularly in the way value moves through the networks, hopefully creating increased returns and incentives for particular producers, systems of production and places. And we are fundamentally interested in the notion of ethics - how ethical production is perceived, enacted and traded. We propose and adopt the concept of Ethical Value Networks (EVeNs). The book describes and theorises the rise of EVeNs and provides a range of case studies at the national and local scales which investigate the detail of the evolution, construction and outcomes of these networks.

This chapter introduces the collection and sets out the purpose and rationale for the work. We start by outlining the concept of EVeNs before tracing the rise of ethical consumption. The uneven and highly asymmetric global agri-food economy is briefly outlined - that which sees capture of value in the core among large-scale TNCs (trans-national corporations) in many globalised sectors. The rise of EVeNs in response has been led by a consumer movement and labelling effort where Northern purchasers 'vote' with their demand decisions. This has led to a burgeoning of market-based movements that seek to incorporate an ethical dimension in trade patterns, such as fair trade, organic production and Geographical Indications (GIs). Following these introductory remarks, we raise several questions with regard to these processes that inform the chapters which follow.

\section{ETHICAL VALUE NETWORKS}

There has been a significant rise in ethically-labelled primary product trade. This has been led in part by shifting taste and behaviours among consumers in the West. Concerned with the rise of uneven and unsustainable trade, there has been a growth in the marketing of agro-commodities that trade on the ethicality of production and delivery. Our concept of EVeNs - these varied and expanding networks of production and trade - builds on work in economic geography and related disciplines on commodity chains, global value chains and global production networks. Ethical value networks are globalised systems that integrate various nodes of productive, distributive and consumption activity across the globe in which, at some stage, a claim for 'ethicality' is certified 
and labelled as such. EVeNs are both a tool of analysis and an aspiration. They have the potential to identify some of the more unjust and non-sustainable aspects of global agri-food networks as the value added is traced through the nodes, flows and relations that comprise the global economy (Bidwell et al., 2018a, 2018b).

\section{Constellations of Ethical Trade}

EVeNs aim to augment the value of commodities through the addition of an 'ethical premium', which seeks to establish, regulate and certify a link between producers and consumers that assures authenticity, social justice and environmental sustainability. In part, EVeNs indicate a greater concern on the part of consumers for equity, environmental protection, food safety and 'authentic', localised production. At the same time, they reflect shifts in the agri-food regime away from Fordist mass-produced commodities towards niche-based export production that emphasises diversification, quality and provenance (Gereffi et al., 2005; Hughes, 2005; Ponte \& Ewert, 2009). In short, EVeNs can be seen as an attempt to re-embed production, or at least to counter-act the disembeddedness that characterises neoliberal globalisation in the first two decades of the 21 st century.

Critically, we see EVeNs as part of a strategy to construct narratives and regulatory frameworks that appeal to consumer tastes and which - perhaps paradoxically - help renew and make profitable neoliberal regimes of accumulation. EVeNs help particular commodities to gain a foothold in global markets by creating and exploiting niches that appeal to discerning consumers in search of ethical, sustainable and place-specific products. Marketeers seek to compete on the basis of factors such as quality, virtue and provenance rather than merely on price. An objective in the construction of ethical value chains and networks is for rural producers to gain a premium for their products and a stable and more just return on their labour as the higher prices paid by ethical consumers supposedly flow back down the chains and networks (McCarthy, 2006; Raynolds, 2012; Raynolds et al., 2007). However, despite these attempts to find alternative food networks and to provide more just, sustainable and supposedly authentic systems of production and trade, we will see that neoliberal processes of appropriation and accumulation continue and have significantly penetrated and even dominated these networks.

The notion that individuals can contribute to social and environmental justice through the exercise of consumer choice has become thoroughly rooted in the Western public imagination. The availability of products with certified normative qualities has grown at an order of magnitude over the past two decades to meet the demand of an expanding base of ethically-minded consumers. The free-market hegemony that emerged in the 1980s has accel- 
erated the transformation of agricultural systems, drawing small farmers into expanded networks of trade in which value and power is increasingly retained at the buying end, and commodity producers are subject to extreme price fluctuations, dependence and insecurity. A consequence of this process has been the intensified fetishisation of food products, which become disembedded from their geographical and social origins, effectively concealing producers from consumers, and rendering unseen the effects of commodity dependence and trade injustice. The asymmetric gains and regional inequalities heralded by globalisation have prompted a transnational mobilisation of loosely organised actors seeking more equitable trade relationships and wealth distribution in commodity networks. This can be conceived as a global social movement, known as the ethical trade movement. Yet whilst this movement in its many different guises is frequently strongly critical of neoliberalism's excesses, proponents often adhere to certain tenets of neoliberalism - namely individualism, consumerism and the ineffectiveness of states in affecting just change. In the case studies that follow in this book, we will see this confused relationship between ethical trade and neoliberalism percolating through many of the resulting EVeNs that are created.

We identify three constellations of ethical trade - social justice, sustainability and authenticity - that comprise a broader universe of EVeNs. The former refers to cases where elements of justice are claimed within networks - most notably involving fair trade. This constellation of EVeNs has grown rapidly in the recent past particularly in products such as coffee, cocoa and bananas, and especially sourced from Latin America. The 'sustainability' constellation refers to EVeNs where environmental imperatives are prioritised, though it can also impinge upon social and cultural notions of health, stability and resilience that allow production and consumption systems to survive well into the future. The rise of organic farming globally and its labelling is central in this regard. We have witnessed an almost bewildering array of labelling efforts in this sector and a sharp rise in consumption of such products, most especially in European markets. Finally, there has been an increase in efforts to capture and protect the authenticity of production - assurances of the place of origin of products. This has been based in part on European models of 'terroir' applied to and codified in the wine sector as Denomination of Origin and broader geographic indications legislation. This concept has spread across the world including to the Global South. In Latin America, for example, we have witnessed a significant rise in the evolution of GI legislation and regulation. Yet we will also see the idea of provenance more broadly than just a guarantee of the place of origin. It can be understood as a fundamental concept that underpins ethicality, including justice and sustainability, in the way it seeks to construct and present narratives about the way certain agro-commodities are produced across time and space. There has been a significant rise in the amount 
of products traded within these three constellations and each of these has seen the rise of systems of labelling and auditing.

The establishment of EVeNs is especially pertinent in resource peripheries. These are national, regional or local economies that have had to compete in an increasingly globalised world market by increasing production of resource-based commodities and seeking low-cost high-volume modes of production. We focus on three broad regions (South Africa, Latin America and South East Asia) that have both varied histories as resource peripheries and similar contemporary experiences seeking alternative trading strategies. Interestingly, these regions remain in competition with one another in exporting many resource-based commodities - they are competitive niches - yet they also have a shared interest in promoting consumer awareness and discrimination.

Our concept of ethical value networks builds on the now extensive literature on global value chains and networks (Bair, 2009; Coe \& Yeung, 2009; Gereffi, 1996, 2014; Gibbon, 2001; Neilson et al., 2014). This work has identified key issues such as governance (Gibbon et al., 2008; Ponte \& Gibbon, 2005) and the way chains are controlled by certain agencies and enterprises within them (Palpacuer, 2008; Pietrobelli \& Saliola, 2008). There has also been research on commodity chains involving fair trade, organics, sustainable production and geographical indications, and some authors have linked value chains to issues of development (Bolwig et al., 2010; Ponte \& Richey, 2014). Yet there is a dearth of research that has tied these various commodity chains together and identified their common foundation in ethical trade and consumer demand. No one has adequately explored the ways such chains are constructed.

However, while gaps remain in our understanding of EVeNs, ethical trade certifications are the subject of a robust discipline-straddling academic literature. Scholars from such diverse fields as business(Beckett \& Nayak, 2008; Brei \& Böhm, 2011; Gendron et al., 2008), anthropology (Fridell et al., 2008; Lyon, 2006), psychology (Bratanova et al., 2015), and geography (Bek et al., 2012; Hughes, 2005; Hughes et al., 2008; McEwan \& Bek, 2009; Mutersbaugh, 2005) have grappled with defining, theorising and evaluating ethical trade. A number of key critiques have emerged from these endeavours. Some of these are grounded in empirical case-study findings and focus on practical limitations to the effectiveness of ethical certifications in protecting vulnerable producers and workers. These limitations include structural barriers to entry which have seen the poorest excluded from ethical networks (Lyon, 2006; Neilson \& Pritchard, 2010), and the difficulties of reconciling conflicting interests within governance structures (Klooster, 2005; Taylor et al., 2005). Some researchers have observed that the increasing standardisation of ethical certifications renders them less able to respond to the subtleties of local contexts and that they constitute a top-down model of development (Freidberg, 2004; 
Mutersbaugh et al., 2005). Other scholarly approaches are concerned with continued asymmetric power and profit distribution within ethically-certified networks, and question which parties are best able to appropriate the 'symbolic capital' generated by certification (Guthman, 2007; Heynen \& Robbins, 2005). It is pointed out that ethical trade initiatives almost inevitably fall subject to the diluting forces of corporate co-optation or appropriation (Fridell et al., 2008; Jaffee \& Howard, 2010). A more theoretical subset of the literature questions the political economy and vision of certification initiatives and points out the fundamental paradoxes of market-led social justice (Fridell, 2006, 2007; Guthman, 2007; Modelo, 2014). These writers raise questions as to the ability of the ethical trade movement to transform neoliberal globalisation.

\section{CENTRAL QUESTIONS OF THIS BOOK}

Although there has been an increase in the volume of research on fair trade, organic production and GIs, and some research on their putative ethical dimensions as noted, very little has been reported on multiple countries and sectors. The literature also fails to address a number of questions relating to the operation of EVeNs at various scales. In this regard, some of the principal questions this work seeks to answer are brought together below. We do not seek to answer the questions definitively or in great depth; rather we provide theoretical and empirical arguments and examples that might facilitate their answering in the future.

1. What is meant by the term 'ethical' when EVeNs are constructed?

2. How are such claims codified and inserted into value chains?

3. What are the impacts of the evolution of EVeNs on the ground?

4. What are the factors driving the adoption of EVeNs at various nodes in the production network?

5. To what extent do the benefits of EVeNs flow to the intended recipients, namely producers in the Global South?

6. Linked to the above, are the local impacts of EVeNs truly ethical as the certification and marketing rhetoric suggests?

7. To what extent can the rise of EVeNs address asymmetric power relations existent in the global agri-food network?

8. How can we conceptualise EVeNs and how do they relate to broader literature concerning chains and networks?

9. How can EVeNs be criticised?

10. What components should be emphasised in further work which seeks to understand the evolution and impact of EVeNs? 
This work has both policy implications as well as theoretical dimensions. Little is known of the comparative impacts of the rise of EVeNs in the Southern Hemisphere, although such knowledge is crucial as demand grows in the expanding global middle class. It has long been accepted that countries outside the cores of the global economy struggle to gain sustainable bases for economic development when they remain largely dependent on the export of primary commodities. Countries in the resource periphery have attempted to develop new export strategies that are more secure and lucrative. It is important that policymakers in the Global South understand better the complexities and possible contradictions within different EVeNs so that more effective regulation or facilitation of ethical production and trade can lead to better desired social and environmental outcomes. In this sense, the book is at once descriptive, analytical and aspirational.

\section{OUTLINE OF THE BOOK}

The first part of the book is theoretical and contextual. Chapter 2 provides a review of the rise of ethical-labelled production focusing on the three constellations - social justice, sustainability and authenticity - as introduced previously. In order to do this we trace the rise of the sectors both at the global level and at lower scales focusing on links between the constellations and the challenges they face. In Chapter 3 we provide a brief overview and analysis of work in economic geography on commodity chains, global value chains, as well as global value networks and identify the gaps which we believe ethical networks can fill. In Chapter 4, we contextualise and theorise ethical value networks and how they might be described, analysed and applied. We reflect on the role of convention theory as well as other concepts that help us to understand the rise of ethical trade focusing on certification. Chapter 5 presents a brief overview of the critiques of ethical trade that have appeared in the literature. These serve to warn us of the potential problems and pitfalls in the implementation of EVeNs and to provide a critical frame of reference for the case studies that follow.

In the second part of the book a range of local case studies based on primary fieldwork is provided. These case studies are based on the research work of Masters and $\mathrm{PhD}$ students of the editors, as well as their own primary fieldwork, undertaken as part of the project that underpins this collection. ${ }^{1}$ These case studies are drawn from Latin America, Africa and Southeast Asia and deal with a range of sectors, including wine, fruit, cinnamon, coffee, and water (see Figure 1.1). Although not intended to be exhaustive, this thematic and geographical range is unique to the literature. The case studies illustrate a wide range of outcomes - cases where ethical-labelling and EVeNs have worked in the favour of producers and labourers and others where they have clearly not. 
At the general level, we make the conclusion that the evolution, construction and outcomes of EVeNs are highly differentiated and context-specific. We make a call for more sensitive geographies of ethicality in this regard. A critical component in future studies is locality studies that pay attention to the specific political economy of the places under consideration and the agents at work, whilst not losing sight of the co-deterministic structure of capital and the power that plays an important conditioning role on outcomes on the ground. These 'whole network' geographies have been largely ignored in the ethical trade literature to date.

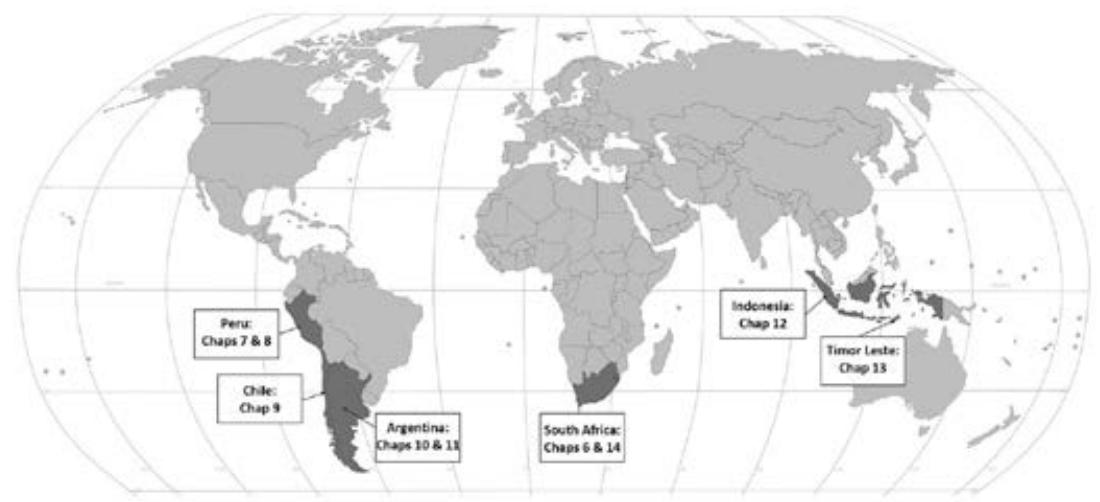

Figure $1.1 \quad$ Location of case studies

In the third part of the book we draw together the challenges and gaps that exist in terms of the evolution and application of EVeNs approaches. We reflect on the role of virtue as it relates to authenticity and provenance as a unifying theme for future geographies of ethicality, tracing out the conceptual challenges faced in the evolution and application of EVeNs theory and policy. We conclude with a review of commonalities, critical issues and remaining questions for the analysis and construction of socially just, sustainable and authentic value networks that place ethical trade at the centre.

\section{NOTE}

1. This book builds in large part from a 4-year research grant (2015-2018 inclusive) entitled 'Re-placing Commodity Dependence: Alternative Sustainable and Ethical Value Chains in the Resource Periphery', led by Professors Warwick Murray and John Overton and also involving Professors Johannes Rehner and Jonathan Barton of Pontificia Universidad Católica, Chile. PhDs by Kelle Howson, Peter Williams and Simon Bidwell as well as numerous Masters theses resulted from this project. Many of the thesis findings appear in this collection as well as broader related 
work by the project leaders and others beyond the immediate group. We gratefully acknowledge the generous financial support of the New Zealand Marsden Fund administered by the Royal Society of New Zealand. We also thank staff in the Research Office at Victoria University of Wellington as well as administrative staff at SGEES at Victoria University of Wellington for their invaluable support.

\section{REFERENCES}

Bair, J. (2009). Global commodity chains. In J. Bair (Ed.), Frontiers of commodity chain research (pp. 1-34). Stanford University Press.

Beckett, A., \& Nayak, A. (2008). The reflexive consumer. Marketing Theory, 8(3), 299-317.

Bek, D., McEwan, C., \& Binns, T. (2012). The South African wine industry: Meeting the challenges of structural and ethical transformation. In P. H. Dougherty (Ed.), The geography of wine (pp. 137-157). Springer.

Bidwell, S., Murray, W. E., \& Overton, J. (2018a). Ethical agro-food networks in global peripheries, Part I: The rise and recommodification of fair trade and organics. Geography Compass, 12(4) online DOI: 10.1111/gec3.12366 11pp

Bidwell, S., Murray, W. E., \& Overton, J. (2018b). Ethical agro-food networks in global peripheries, Part II: Re-placing commodity dependence. Geography Compass, 12(4) online DOI: $10.1111 / \mathrm{gec} 3.1236511 \mathrm{pp}$

Bolwig, S., Ponte, S., Du Toit, A., Riisgaard, L., \& Halberg, N. (2010). Integrating poverty and environmental concerns into value-chain analysis: A conceptual framework. Development Policy Review, 28(2), 173-194.

Bratanova, B., Vauclair, C.-M., Kervyn, N., Schumann, S., Wood, R., \& Klein, O. (2015). Savouring morality. Moral satisfaction renders food of ethical origin subjectively tastier. Appetite, 91, 137-149.

Brei, V., \& Böhm, S. (2011). Corporate social responsibility as cultural meaning management: a critique of the marketing of 'ethical' bottled water. Business Ethics: A European Review, 20(3), 233-252.

Coe, N. M., \& Yeung, H. W. C. (2019). Global production networks: Mapping recent conceptual developments. Journal of Economic Geography, 19(4), 775-801.

Freidberg, S. (2004). The ethical complex of corporate food power. Environment and Planning D: Society and Space, 22(4), 513-531.

Fridell, G. (2006). Fair trade and neoliberalism: Assessing emerging perspectives. Latin American Perspectives, 33(6), 8-28.

Fridell, G. (2007). Fair trade coffee: The prospects and pitfalls of market-driven social justice. University of Toronto Press.

Fridell, M., Hudson, I., \& Hudson, M. (2008). With friends like these: The corporate response to fair trade coffee. Review of Radical Political Economics, 40(1), 8-34.

Gendron, C., Bisaillon, V., \& Rance, A. I. O. (2008). The institutionalization of fair trade: More than just a degraded form of social action. Journal of Business Ethics, $86(1), 63-79$.

Gereffi, G. (1996). Global commodity chains: new forms of coordination and control among nations and firms in international industries. Competition and Change, 1(4), 427-439.

Gereffi, G. (2014). Global value chains in a post-Washington Consensus world. Review of International Political Economy, 21(1), 9-37. 
Gereffi, G., Humphrey, J., \& Sturgeon, T. (2005). The governance of global value chains. Review of International Political Economy, 12(1), 78-104.

Gibbon, P. (2001). Upgrading primary production: A global commodity chain approach. World Development, 29(2), 345-363.

Gibbon, P., Bair, J., \& Ponte, S. (2008). Governing global value chains: An introduction. Economy and Society, 37(3), 315-338.

Guthman, J, (2007). The Polanyian way? Voluntary food labels as neoliberal governance. Antipode, 39(3), 456-478.

Heynen, N., \& Robbins, P. (2005). The neoliberalization of nature: Governance, privatization, enclosure and valuation. Capitalism Nature Socialism, 16(1), 5-8.

Hughes, A. (2005). Geographies of exchange and circulation: Alternative trading spaces. Progress in Human Geography, 29(4), 496-504.

Hughes, A., Wrigley, N., \& Buttle, M. (2008). Global production networks, ethical campaigning, and the embeddedness of responsible governance. Journal of Economic Geography, 8(3), 345-367.

Jaffee, D., \& Howard, P. (2010). Corporate co-optation of organic and fair trade standards. Agriculture and Human Values, 27, 387-399.

Klooster, D. (2005). Environmental certification of forests: The evolution of environmental governance in a commodity network. Journal of Rural Studies, 21(4), 403-417.

Lyon, S. (2006). Evaluating fair trade consumption: Politics, defetishization and producer participation. International Journal of Consumer Studies, 30(5), 452-464.

McCarthy, J. (2006). Rural geography: alternative rural economies - the search for alterity in forests, fisheries, food, and fair trade. Progress in Human Geography, 30(6), 803-811.

McEwan, C., \& Bek, D. (2009). The political economy of alternative trade: Social and environmental certification in the South African wine industry. Journal of Rural Studies, 25(3), 255-266.

Modelo, M. (2014). The paradox of fair trade. Stanford Social Innovation Review. Retrieved from http://ssir.org/articles/entry/the_paradox_of_fair_trade

Mutersbaugh, T. (2005). Just-in-space: Certified rural products, labor of quality, and regulatory spaces. Journal of Rural Studies, 21(4), 389-402.

Mutersbaugh, T., Klooster, D., Renard, M.-C., \& Taylor, P. (2005). Certifying rural spaces: Quality-certified products and rural governance. Journal of Rural Studies, 21(4), 381-388.

Neilson, J., \& Pritchard, B. (2010). Fairness and ethicality in their place: The regional dynamics of fair trade and ethical sourcing agendas in the plantation districts of South India. Environment and Planning A, 42(8), 1833-1851.

Neilson, J., Pritchard, B., \& Yeung, H. W. C. (2014). Global value chains and global production networks in the changing international political economy: An introduction. Review of International Political Economy, 21(1), 1-8.

Palpacuer, F. (2008). Bringing the social context back in: Governance and wealth distribution in global commodity chains. Economy and Society, 37(3), 393-419.

Pietrobelli, C., \& Saliola, F. (2008). Power relationships along the value chain: Multinational firms, global buyers and performance of local suppliers. Cambridge Journal of Economics, 32(6), 947-962.

Ponte, S., \& Ewert, J. (2009). Which way is 'up' in upgrading? Trajectories of change in the value chain for South African wine. World Development, 37(10), 1637-1650.

Ponte, S., \& Gibbon, P. (2005). Quality standards, conventions and the governance of global value chains. Economy and Society, 34(1), 1-31. 
Ponte, S. \& Richey, L. A. (2014) Buying into development? Brand aid forms of cause-related marketing. Third World Quarterly, 35(1), 65-87.

Raynolds, L. T. (2012). Fair trade: Social regulation in global food markets. Journal of Rural Studies, 28, 276-287.

Raynolds, L. T., Murray, D., \& Heller, A., (2007). Regulating sustainability in the coffee sector: A comparative analysis of third party environmental and social certification initiatives. Agriculture and Human Values, 24(2), 147-163.

Taylor, P. L., Murray, D. L., \& Raynolds, L. T. (2005). Keeping trade fair: Governance challenges in the fair trade coffee initiative. Sustainable Development, 13(3), 199-208. 